\title{
ONCIDIUM ZELENKOANUM (ORCHIDACEAE), AN UNUSUAL NEW SPECIES FROM PANAMA
}

\author{
Robert L. Dressler ${ }^{1}$ and Franco PUPULIN ${ }^{2}$ \\ ${ }^{1}$ Missouri Botanical Garden, Florida Museum of Natural History, Marie Selby Botanical Gardens \\ Mailing address: 21305 NW 86th Ave., Micanopy, Florida 32667, USA - rdressl@ nersp.nerdc.ufl.edu \\ ${ }^{2}$ Jardín Botánico Lankester, Universidad de Costa Rica, P.O. Box 1031-7050 Cartago, Costa Rica, A.C. \\ Research Associate, Marie Selby Botanical Gardens, Sarasota, USA - fpupulin@ cariari.ucr.ac.cr
}

\begin{abstract}
RESUMEN. Se describe una nueva especie, Oncidium zelenkoanum, de Panamá occidental. Parece ser una especie aislada, sin parientes cercanos conocidos en Centroamérica. Las alas de la columna tienen lóbulos su-bulados, porrectos, que recuerdan las "aristas" o "cirros" de algunas especies de Odontoglossum.

Abstract. A new species, Oncidium zelenkoanum, is described from western Panama. It appears to be an isolated species, without known close relatives in Central America. The column wings have subulate, distal lobules that resemble the "awns" or "cirrhi" of some species of Odontoglossum.
\end{abstract}

Key words / Palabras clave: Oncidium zelenkoanum, Orchidaceae, Panama.

Oncidium is one of the most problematic of the familiar orchid genera. Traditionally, it included very diverse plants and flowers. Now, comparison of DNA is showing that the traditional concept of Oncidium is quite artificial. The "Mule-ears" and the "Rat-tails" are much closer to Trichocentrum than to Oncidium, and some other groups of "Oncidium" are only distantly related to each other. The new species to be described here looks, at first glance, very like many species of Oncidium, but on closer inspection, it has some unusual features, and preliminary molecular analysis suggests that it is intermediate between Oncidium and Odontoglossum (N. H. Williams, pers. comm.). It is an attractive species and is now widely cultivated, so that a valid name is needed for the species, even though it may not remain in Oncidium for long.

Erick Olmos reports that this species was seen by orchid collectors many years ago, but was relocated again only recently. It apparently grows high in the trees, and is thus rarely seen except where tall trees are being cut. In its details, it does not agree with any Oncidium known to us. The basal portion of the lip is much larger than the midlobe, and in many cases the lobes of the midlobe remain folded together, making this part of the lip even less conspicuous. The callus is made up of several irregular ridges and points downward toward the lip apex. The column is narrow basally and rather arched. On each side the column wings form a prominent sublaciniate lobe somewhat below the stigma, but another narrow lobe runs toward the anther and forms 1 to 3 narrowly subulate lobes next to the anther. These narrow lobes are reminiscent of the "cirrhi" of many species of Odontoglossum, rather than Oncidium. When Dr. Williams' analyses are ready for publication, then, we cannot guarantee that this species will remain in Oncidium, however, the species is now in cultivation, and should be given a specific epithet, even though the generic name may change.

Oncidium zelenkoanum Dressler \& Pupulin, sp. nov.

TYPE: PANAMA. Bocas del Toro: Culebra (Velorio), alt. $1000 \mathrm{~m}$, nov. 2000, epífita en árboles muy altos, amarillo con castaño obscuro, floreció en cultivo julio 2001, A. Maduro y E. Olmos 195 (Holotype, MO; Isotype, PMA).

FIG. 1.

Herba caespitosa, pseudobulbi ovoidei, folia oblonga vel elliptico-oblonga, subpetiolata, inflorescentia ramosa, labellum subpanduriforme, base lobulo mediano multo latiore, columna arcuata, basi gracilior, alis sub stigma ornata, lobuli apicales uno-tribus cirrhis subuliformis.

Epiphytic herb, caespitose; roots $0.5-1 \mathrm{~mm}$ in diameter; pseudobulbs ovoid, complanate, spotted with dark red, $2.5-5 \times 1.4-2.7 \mathrm{~cm}$; each with 1 termi- 


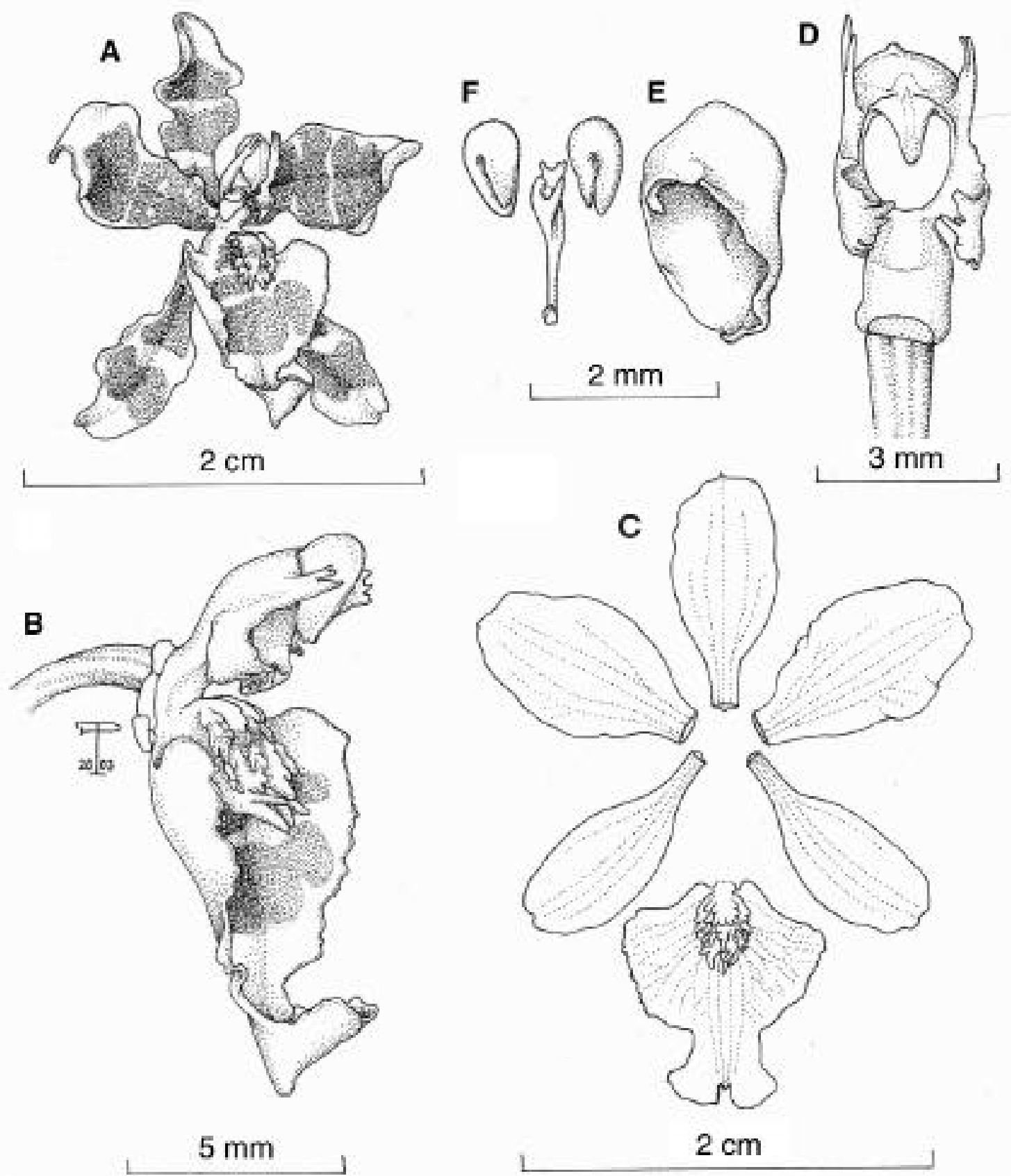

Figure 1. Oncidium zelenkoanum Dressler \& Pupulin. A - Flower. B - Lateral view of column and lip. C - Perianth parts, flattened. D - Column, ventral view. E - Anther. F - Stipe and pollinia. From flowers of the type collection preserved in alcohol.

nal leaf and 2-3 sheathing leaves, leaves 12-25 x 0.9$3.2 \mathrm{~cm}$, oblong or elliptic-oblong, subpetiolate, narrowed for 1.2-2.5 cm, sheaths 3-6 cm; inflorescence lateral, paniculate, peduncle $8-20 \mathrm{~cm}$; panicle $15-40$ $\mathrm{cm}$; floral bracts 2-3.5 $\times 2-3 \mathrm{~mm}$, triangular, acute; ovary and pedicel 5-6.5 mm; flowers yellow, boldly 
marked with dark red-brown; dorsal sepals 10-11 x 4$6 \mathrm{~mm}$, unguiculate, oblong-obovate or oblong-ovate, obtuse; lateral sepals 10-10.5 × 3.2-4.5 mm, unguiculate, oblong-obovate or oblong-ovate, acute; petals 10-10.5 x 5-7 mm, cuneate, obovate, obtuse or apiculate to acute; lip 9-10 x 8.5-9 mm, base minutely cordate, then broadly cuneate, unequally pandurate and abruptly expanding, widest in basal $1 / 4$, then narrowed, somewhat pandurate, isthmus $c a .2 \mathrm{~mm}$ wide, midlobe 3-4 × $2 \mathrm{~mm}$, deeply emarginate, apiculate; callus $4 \times 2.2 \mathrm{~mm}$, ovoid, with 4-5 low, irregular keels, distally acute; column 3.5-4 mm, convex dor- sally, narrow basally, column wings 2-lobed, the basal lobe $c a .1 .5 \times 1.5 \mathrm{~mm}$, sublacerate, slightly below stigma, distally with 1-3 narrow, subulate lobules parallel with column axis, next to anther.

This species appears to have no known close allies. The column wings are quite unlike any other known to us, and the shape of the lip is equally distinctive. Andrew Maduro suggested that the new species be named O. zelenkoanum, in recognition of Harry Zelenko's contribution to our knowledge of Oncidium and its allies. 